Global Conferences Series:

Social Sciences, Education and Humanities (GCSSSEH), Volume 6, 2020

International Conference Fakultas Tarbiyah dan Keguruan Universitas Islam Negeri Imam Bonjol Padang (ICFTKUINIBP) 2020

DOI: https://doi.org/10.32698/icftk397

\title{
The Weakness of Human in Perspective of Qur'an
}

\section{Kelemahan Manusia Dalam Prespektif Al-Quran}

\author{
Arief Rahman Hakim ${ }^{\text {a }}$, Zulheldi $^{\mathbf{a}}$, Rusydi A ${ }^{\mathbf{a}}$ \\ ${ }^{a}$ Universitas Islam Negeri Imam Bonjol, Padang, Indonesia \\ E-mail:kimsay1310@gmail.com
}

\begin{abstract}
In the holy Qur'an the human is stated as the perfect creature. In others side used as the reason said that the human own the bad behaviour, tyranical, stupid, leisure and others. Whether the bad behaviour reduces the perfectness of the human of its creature or just the bad behaviour has the high quality of the human by the God (Allah). This journal is led to know what the weakness of human are, cause and effect that put the human and the solution of Qur an to handle of the weakness of human. The methode which in used in this research is Maudhu i methode. The resources of data primer is al-Qur`an and secunder resources are the exegeses books (tafsir Qur`an) which supports this research. The result of the research shows that between of solution thats Qur`an given to the human are; First, put the Qur`an and prophet saying as the guidance of live. Second, put ourselve and keep doing what Allah ask to do as the life regulation. Third, get the lesson and guidance in order the human could get the high perfectness in the God perception.
\end{abstract}

Keywords: Weakness, human, perspective of qur'an

\section{PENDAHULUAN}

Pembahasan tentang hakikat manusia merupakan suatu persoalan klasik yang sulit untuk dipecahkan secara tuntas. Ibn 'Arabi memberikan gambaran mengenai hakikat manusia, beliau menyatakan bahwa " Tidak ada makhluk Allah Swt. yang lebih sempurna kecuali manusia, yang mempunyai daya hidup, mengetahui, memiliki kehendak, dapat berbicara, melihat, memutuskan dan berfikir". Manusia merupakan makhluk kosmis yang penting artinya, hal ini dikarenakan pada diri manusia dilengkapi dengan seluruh pembawaan atau fitrah dan syarat yang dibutuhkan untuk menjalankan tugas serta fungsinya sebagai makhluk ciptaan Allah Swt. di muka bumi. (Ismai Raji’ Al-Faruqi: 1984)

Dalam pandangan filsafat, hakekat manusia merupakan suatu mahkluk yang sangat unik. Upaya dalam memahami hakekat manusia ini sudah dilakukan sejak zaman dahulu kala. Namun, pernyataan yang tepat mengenai hakekat manusia belum didapatkan secara pasti, hal ini dikarenakan manusia itu sendiri merupakan makhluk yang unik, yang memiliki perbedaan antara manusia yang satu dengan yang lainnya. Bahkan untuk manusia yang kembar indentik sekalipun, tetap memiliki perbedaan antara satu dan lainnya, baik secara fisik, pemahaman, ideologi, prilaku, kepentingan dan lain-lain. Hal inilah yang menyebabkan suatu pernyataan mengenai hakekat manusia belum tentu tepat dan disetujui oleh sebagian orang.

Sebutan manusia menurut para ahli filsafat dan ahli pikir dapat disesuaikan dengan kemampuan yang dilakukannya di bumi ini, diantaranya; a. Manusia merupakan Homo Sapiens dimana hal ini berarti manusia merupakan makhluk yang berbudi, b. Manusia merupakan Animal Rational yang artinya binatang yang berfikir, c. Manusia merupakan Homo Laquen yang berarti makhluk yang dapat menciptakan bahasa dan menjelmakan pikiran serta perasaan ke dalam kata-kata yang tersusun, d. Manusia merupakan Homo Faber, yaitu merupakan makhluk yang terampil, dapat membuat perkakas atau peralatan yang disebut juga dengan Tool Making Animal yang berarti binatang yang pandai membuat alat-alat, e. Manusia merupakan Zoon Politicon, yaitu makhluk yang pandai bergaul dan bekerjasama dengan manusia lainnya serta dapat mengorganisasikan diri untuk memenuhi kebutuhan hidupnya, f. Manusia merupakan Homo Economicus,

Copyright (C) 2020, the Authors. Published by Redwhite Press. 
yang berarti bahwa manusia tunduk pada prinsip ekonomi dan bersifat ekonomis, g. Manusia merupakan Homo Religious yang artinya manusia merupakan makhluk yang memiliki agama. (Hamdani Ihsan : 2007)

Dalam pandangan Islam, ada beberapa konsep yang digunakan di dalam al-Qur'an mengenai makna manusia, namun makna manusia yang digunakan al-Qur'an ini secara khusus mempunyai penekanan yang berbeda-beda. Perbedaan tersebut terlihat pada konsep-konsep berikut:

Pertama: Mengenai konsep al-Basyar. Kata al-Basyar baik dalam bentuk tasniyah maupun mufrad, di dalam al-Qur'an diulang-ulang sebanyak 37 kali dan kata ini ditemukan pada 26 surat. Satu kali dalam bentuk tasniyah dan sebanyak 36 kali dalam bentuk mufrad (tunggal). Sebanyak 12 dari 37 kali kata alBasyar diulang dalam al-Qur'an, hanya 4 kali saja disebutkan dalam surat Madaniyah yaitu pada Q.S. Ali 'Imran:47,79, Q.S al-Maidah:18, dan Q.S al-Taghabun:6. Sedangkan 33 kali disebutkan di dalam surat Makkiyah. Kata al-Basyar secara etimologi berarti mulamasah, yaitu merupakan persentuhan kulit antara perempuan dan laki-laki. Dari pernyataan tersebut dapat dipahami maknanya, bahwa manusia adalah makhluk yang mempunyai semua sifat-sifat kemanusiaan yang memiliki batas, misalnya makan, minum, seks, rasa aman, rasa bahagia, dan lain-lain. Kata al-Basyar yang ada dalam al-Qur'an ditujukan Alah Swt kepada seluruh umat manusia tanpa pengecualian. Demikian juga halnya dengan rasul-rasul-Nya. Bedanya kepada para rasul-rasul-Nya diberi wahyu, sedangkan umat manusia lainnya tidak medapatkan wahyu. Dari konsep al-Basyar yang telah dijelaskan pada pernyataan tersebut, dapat dipahami bahwa manusia tidak beda jauh dengan makhluk biologis lain, kehidupan manusia terkait dengan kaidah-kaidah serta prinsip-prinsip kehidupan biologis, misalnya berkembang biak, tumbuh dan berkembang serta fase pencapaian tingkat kematangan dan kedewasaan.

Kedua: Mengenai konsep al-Insan. Di dalam al-Qur'an kata al-Insanterdapat sebanyak61 kali. (Muhammad Fuad Abd al-Baqi : 1998)Terdapat perbedaan pendapat di kalangan para ulama mengenai asal kata al-Insan secara etimologi (bahasa). Menurut sebagian ulama, al-Insan asal katanya yaitu Nasawa artinya bergerak. Ulama lain ada yang mengatakan asal kata al-Insan yaitu Anasa yang artinya jinak, ada juga yang mengatakan berasal dari kata Nasiya yang artinya lupa. Begitupun halnya penamaan manusia dengan kata al-Insan yang asal katanya al-Uns, kata ini disebut dalam al-Qur'an sebanyak 73 kali dan ada atau terdapat di dalam 43 surat. (Shihab al-Din Ahmad Ibn Muhammad al-Haim : 1992)Al-Insan secara etimologi atau bahasa berarti harmonis, lemah lembut, tampak atau pelupa. Selain itu ada juga yang menyebutkan bahwa kata alInsan akar katanya Naus yang berarti "pergerakan atau dinamisme ". Merujuk dari asal kata al-Insan seperti yang telah disebutkan sebelumnya dapat dipahami bahwa manusia pada dasarnya mempunyai suatu potensi yang positif untuk dapat berkembang baik, secara fisik maupun secara mental spiritual. Selain itu manusia juga dibekali dengan berbagai potensi, yang memberikan peluang untuk mendorongnya ke arah prilaku, tindakan, maupun sikap yang negatif yang dapat merugikannya.

Ketiga: Mengenai konsep al-Nas. Dalam al-Qur'an kata al-Nas dinyatakan sebanyak 240 kali yang terdapat pada 53 surat. Kata ini merujuk pada eksistensi manusia sebagai makhluk hidup dan makhluk sosial. Kata ini merujuk pada eksistensi manusia secara keseluruhan tanpa melihat status keimanan dan kekafiran seseorang. Dalam al-Qur'an kata al-Nas digunakan untuk menyatakan adanya sekelompok manusia atau masyarakat yang memiliki berbagai macam aktivitas untuk mengembangkan kehidupannya. (Musa Asy'ari : 1992) Manusia merupakan makhluk ciptaan Allah Swt. yang diciptakan bermasyarakat, awalnya dimulai dari sepasang laki-laki dan perempuan yang kemudian berkembang bersuku-suku dan berbangsa-bangsa agar saling kenal "berinteraksi". Pernyataan ini sejalan dengan teori "struktualisme" yang dikemukakan oleh Giddens yang menyatakan bahwa manusia merupakan suatu induvidu yang memiliki karakter dan prinsip yang berbeda-beda antara satu dan yang lainnya, tetapi manusia juga merupakan suatu agen sosial yang dapat mempengaruhi atau bahkan dipengaruhin atau dibentuk oleh suatu masyarakat dan kebudayaan dimana ia berada dalam konteks sosial. (Brian Fay : 2002)

Ke-empat: Mengenai konsep kata al-Ins. Kata ini dalam al-Qur'an digunakan sebanyak 18 kali dan selalu ditandemkan dengan kata al-Jinn atau Jann. Merujuk pada penggunaan kata al-Ins dalam al-Qur'an, maksud dari kata ini yaitu merupakan jenis makhluk sehingga kata ini juga diperhadapkan dengan jenis jin. Di dalam al-Qur'an kata al-Jin digambarkan sebagai suasana yang mencekam, mengerikan, kebuasan dan kekacauan. Sedangkan kata al-Ins digambarkan sebagai lawan katanya yang bermakna lembut, jinak, dan kedamaian. Dalam kitab "Mu jam Maqayis al-Lughah” karya Abi al-Husain Ahmad Zakariya dan "Mu'jam Gharib al-Qur'an li al-Ashfahani” lafas al-Ins berbeda dari al-Jin. Pada "Mu'jam Gharib al-Qur'an li alAshfahani" ditambahkan bahwa kata al-Ins artinya berbeda juga dari sekelompok orang, hal ini dikarenakan adanya banyak sifat ramah atau senang, sehingga kemudian dikatakan sebagai hewan yang jinak.

Kata al-Ins asal dari akar katanya sama dengan kata al-Nas, al-Insan. Kata ini berasal dari tiga huruf yaitu Alif, Nun, dan Sin. Letak perbedaan diantara kata al-Ins, al-Insan dan al-Nas yaitu kata al-Ins dipakai 
untuk menunjukkan jenis manusia itu sendiri, karena itu kata ini selalu disandingkan dengan kata al-Jin. Selain itu pada beberapa konteks kata al-Ins sering dimaknai sebagai suatu golongan atau individu.

Kelima: Mengenai konsep kata bani Adam. Kata ini diartikan sebagai keturunan Adam a.s. Istilah bani Adam, dipakai untuk menyebutkan manusia bila merujuk pada asal keturunannya. Di dalam al-Qur'an kata ini diulang sebanyak 7 kali, sekali menggunakan ibnai Adam (dalam bentuk tasniyah atau dua) dan hanya sekali dengan menggunakan kata zurriyah. Thabathaba'i dalam "Syamsal-Nizar" menyatakan bahwa penggunaan kata bani Adam merujuk pada arti manusia secara umum. Dalam hal ini, ada tiga aspek yang dikaji. Pertama, anjuran untuk berbudaya yang sesuai dengan ketentuan yang telah di tetapkan Allah Swt. misalnya menggunakan pakaian, untuk menutupi aurat. Kedua, mengingatkan umat manusia keturunan Adam a.s agar jangan sampai terjerumus godaan syetan yang selalu membawa manusia ke dalam keingkaran. Ketiga, memanfaatkan segala yang ada di alam semesta ini untuk ibadah semata dan mentauhidkan-Nya. Semua ini, merupakan anjuran dan peringatan dari Allah Swt. yang ditujukan untuk memuliakan manusia sebagai keturunan Adam a.s. dibanding makhluk ciptaan-Nya yang lain.

Menyangkut keberadaannya, telaah mengenai ayat-ayat al-Qur'an yang membahas mengenai manusia memberikan gambaran yang kontradiktif. Disatu sisi bahasan mengenai manusia selalu mendapat pujian dari Tuhan, misalnya pernyataan mengenai terciptanya manusia dalam bentuk dan keadaan yang sebaik-baiknya, yang kemudian diikuti dengan penegasan dimuliakannya makhluk ini dibandaingkan dengan kebanyakan mahkluk-makluk lainnya. Firman Allah Swt. Q.S al-Tin ayat: 4.

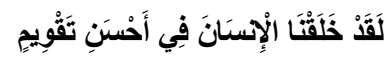

Artinya: "Sesungguhnya Kami telah menciptakan manusia dalam bentuk yang sebaik-baiknya". (Q.S al-Tin ayat: 4)

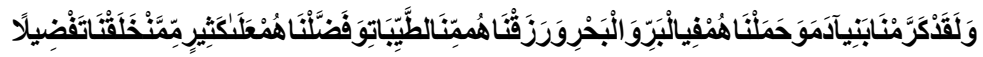

Artinya: "Dan sesungguhnya telah Kami muliakan anak-anak Adam, Kami angkut mereka di daratan dan di lautan, Kami beri mereka rezeki dari yang baik-baik dan Kami lebihkan mereka dengan kelebihan yang sempurna atas kebanyakan makhluk yang telah Kami ciptakan”. (Q.S al-Isra ayat: 70).

Pada sisi lainnya, manusia juga sering mendapat celaan dari Allah Swt., seperti bahwa ia amat aniaya dan ingkar nikmat, bersifat keluh kesah lagi kikir dan sangat banyak membantah serta sangat zalim dan bodoh. (Muhammad Quraish Shihab: 1994) Firman Allah Swt dalam surat al-Ahzab ayat: 72

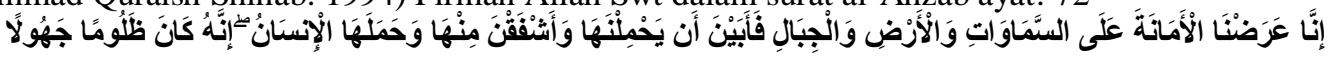

Artinya: “ Sesungguhnya Kami telah mengemukakan amanat kepada langit, bumi dan gununggunung, maka semuanya enggan untuk memikul amanat itu dan mereka khawatir akan mengkhianatinya, dan dipikullah amanat itu oleh manusia. Sesungguhnya manusia itu amat zalim dan amat bodoh”. (Q.S al-Ahzab ayat: 72).

Maksud dari zalim dan bodoh yang Allah Swt sebutkan pada ayat ini adalah, manusia dengan kebodohannya mau menerima tanggung jawab berupa beban hukum taklif, kemudian setelah manusia menerima amanah beban taklif tersebut manusia melakukan perbuatan zalim karena manusia tidak menjalankan amanah dari beban taklif tersebut.

Dalam tafsir al-Maraghi karya Ahmad Mustafa Al-Maraghi disebutkan bahwa; Kata (العرض) yang dimaksud ialah melihat kepada kesiapan langit dan bumi. Kemudian (الأمانة): segala sesuatu yang dipercayakan kepada seseorang baik berupa perintah maupun larangan, tentang urusan-urusan agama dan dunia. Dan yang dimaksud ialah beban agama, karena merupakan hak-hak yang diwajibkan oleh Allah Swt atas orang-orang mukallaf serta disuruh menjaga dan melaksankannya tanpa melalaikan sedikitpun darinya. Kemudian amanat tersebut ditolak oleh langit, bumi dan gunung-gunung karena mereka tidak siap menerimanya dan dipikullah oleh manusia karena mereka merasa siap menerima amanat tersebut, namun karena kebodohannya tentang akibat-akibat segala perkara, akibat diliputi kekuatan syahwat maka manusia disebut dengan zalim dan bodoh sebagaimana firman Allah Swt diakhir ayat (إنّهكانظلوماجهو لا

Gambaran dari bentuk kontradiktif tersebut, bukan berarti bahwa ayat-ayat yang berbicara tentang manusia bertentangan satu dengan yang lainnya, akan tetapi justru menunjukkan bahwa makhluk yang bernama manusia adalah makhluk yang unik, makhluk yang serba dimensi, dan makhluk yang berada dalam predisposisi positif dan negatif. Hal ini dapat dipahami dengan mengkaji asal-usul kejadian dan proses penciptaannya, serta keragaman terminologinya dalam al-Qur'an.

Dalam pandangan Islam, manusia selalu dihubungkan dengan suatu kisah tersendiri. manusia di dalam al-Qur'an tidak hanya digambarkan sebagai hewan tingkat tinggi semata, namun juga ditinggikan berulang kali derajatnya dan direndahkan berulang kali juga. Manusia dihargai sebagai suatu makhluk yang dapat 
menaklukkan alam, namun dapat juga merosot menjadi “yang paling rendah dari segala yang rendah". Dengan demikian, nasib akhir dari manusia itu sendiri, manusialah yang harus menentukan dan menetapkannya (Murtadha Muthahhari : 1997)

Kemudian bagaimana kelemahan atau kekurangan manusia di dalam al-Qur'an serta apa solusi yang diberikan al-Qur'an dalam mengatasi kelemahan tersebut?

\section{METODE}

Dalam melakukan suatu kegiatan yang sifatnya ilmiah, diperlukan suatu metode yang sesuai dengan masalah yang sedang dikaji, supaya kegiatan penelitian berjalan secara rasional dan terarah serta untuk memperoleh hasil yang memuaskan, maka metode yang peneliti gunakan dalam penelitian ini adalah Metode Maudhuiy, karena metode ini memberikan kemudahan dalam mengumpulkan ayat atau isi tema yang sama yang ada di dalam al-Qur`an.

Diantara ciri-ciri atau langkah dalam metode maudhu i, adalah:

1. Mengumpulkan atau menghimpun ayat-ayat yang ada di dalam al-Qur'an yang berkaitan dengan masalah atau tema yang sama dari berbagai surat-surat.

2. Objek penafsirannya bukanlah dilakukan ayat demi ayat yang susunannya sesuai dengan urutan dalam al-Qur'an seperti pada tafsir Tahlili.

3. Sebelum dilakukan penafsiran ayat-ayat dengan metode maudhu'i, setiap ayat dan lafas yang terkandung di dalam ayat tersebut haruslah dipahami dan ditinjau terlebih dahulu, baik dari segi bahasa, konteks kesejarahan, munasabat, dan lain sebagainya.

4. Pada tafsir maudhu'i ini arah bahasannya terfokus pada satu topik yang telah ditetapkan.

5. Pada tafsir maudhu'i, tujuan utama yang diharapkan bukan hanya sekedar mengetahui i'jaz al-Qur'an seperti keindahan bahasa, ketinggian nilai sastra atau kehebatan-kehebatan al-Qur'an lainnya, melainkan memahami makna dan hidayah dari al-Qur'an itu sendiri.

Sumber data primer pada penelitian ini yaitu al-Qur'an al- Karim. Sedangkan sumber data sekunder pada penelitian ini yaitu; kitab-kitab tafsir seperti, "Fi zhilal al-Qur'an" karya dari Sayid Qutub, Tafsir "alThabari "karya dari Ibn Jarir al-Thabari, Tafsir "Ibn Katsir”, "al-Kasyaf” karya dari al-Zamakhsyari dan juga kitab-kitab tafsir lain yang dapat mendukung dan sesuai dengan bahasan pada penelitian ini.

\section{PEMBAHASAN}

Kelemahan manusia apabila kita lihat dari berbagai sudut pandang perspektif, maka manusia dalam pandangan Islam adalah: Sifat-sifat negatif manusia yang telah Allah Swt. jelaskan di dalam al-Qur`an, semuanya terkait dengan sikap manusia terhadap nikmat yang telah diberikan kepadanya. Sifat negatif tersebut muncul diantaranya ketika nikmat itu menjadi hilang dan tidak dapat dirasakan lagi karena satu dan lain hal, yang mana hal tersebut hendaknya menjadi pelajaran dan selalu bersikap normal, wajar dan tidak terlampau senang saat mendapatkan nikmat, karena semua yang terjadi dalam kehidupan memiliki siklus yaitu ada saatnya hal tersebut dipunyai dan ada pula saat dimana tidak bisa dimiliki. Manusia juga harus yakin bahwasanya semua yang diterima pada hakikatnya merupakan titipan dan pemberian dari Yang Maha Kuasa, sehingga ketika ada maupun tiada, banyak maupun sedikit manusia mampu menyikapinya dengan benar.

Dalam semua ayat yang memberikan penjelasan mengenai kelemahan sifat manusia, salah satu kata yang digunakan Allah Swt. yaitu al-Insan. Hal ini karena menjurus kepada manusia sebagai mahkluk psikis yang mempunyai mental sikap dan karakter tersendiri. Semua kelemahan manusia yang disebutkan di dalam al-Qur'an lebih membahas mengenai sifat, sikap, dan karakter.

Namun demikian, semua sifat dan karakter manusia tersebut dapat diantisipasi dan diperbaiki, karena tidak semua orang yang memiliki sifat-sifat kelemahan manusia tersebut, tidak memiliki bukan berarti tidak ada potensi untuk tidak memiliki sifat tersebut, melainkan mereka paham mengenai kelemahan tersebut dan bahaya yang diakibatkannya, lalu mereka mengantisipasi dengan menghindari atau memperbaiki kelemahan tersebut agar tidak menjadi watak yang menjadi satu dengan dirinya.

Diantara kelemahan manusian yang ada dalam al-Qur'an adalah; a) Manusia lemah Q.S al-Nisa` ayat 28, b) Manusia selalu tergesa-gesa Q.S al-Ma`arij ayat: 19-21, Q.S al-Ahzab ayat: 37, Q.S al- Isra` ayat: 11, c) Bersifat zalim Q.S al-Ahzab ayat 72, Q.S Ibrahim ayat:34, d) Manusia merugi Q.S al-Syams ayat: 7-10, Q.S al-'Ashr ayat: 1-4, e) Kembali ke tempat yang hina Q.S al-Tin ayat: 4-5, f) manusia lalai dan lengah Q.S al-A raf ayat: 172, 179, g) Suka membantah Q.S al-Kahfi ayat: 54, h) Suka putus asa Q.S Hud ayat: 9-10, 
Q.S ayat: Fushilat ayat: 49, i) Manusia khianat Q.S al-Nisa` ayat: 107, j) Mengikuti hawa nafsu Q.S Yusuf ayat: 53, k) Pembantah Q.S al-Nahl ayat:4, 1) Kikir Q.S al-Isra` ayat: 100, m) Melampaui batas Q.S Yunus ayat: 12, Q.S al-`Alaq ayat: 6-7, n) Lupa kepada Allah Swt Q.S al-Zumar ayat: 8.

Sedangkan kelemahan manusia dalam pandangan filsafat dapat disimpulkan bahwa: Terlepas dari keseluruhan sifat luhur yang dimilikinya, manusia pada dasarnya mempunyai kodrat hewani yang tertanam jauh di dalam diri manusia itu sendiri. Kondrat hewani inilah yang kemudian memungkinkan manusia bertindak kejam terhadap manusia lain dan terlepas dari semua sebab ekonomis dan politis berubah dan berkumpul sebagai massa.

Manusia juga memiliki masa yang merupakan produk dari kemampuan manusia untuk mengubah dirinya mempunyai dua sisi. Sisi pertama, merupakan sisi merusak, misalnya ketika dalam perang, memberontak, membuat kerusuhan, konflik antar golongan manusia dan lain-lain. Pada fenomena-fenomena tersebut, terlihat dengan jelas sisi hewani manusia yang merusak. Sisi kedua, merupakan sisi mencipta. Kehadiran massa ini juga sering sebagai pertanda lahirnya era baru, contohnya revolusi damai dimana hal tersebut merupakan bagian dari massa manusia yang melakukan perbahan pada tata sosial hingga akhirnya mengubah dunia itu sendiri.

Kemudian kelemahan manusia dalam pandangan psikologi, apabila melihat pola kepribadian manusia dalam al-Qur`an dari sisi negatif, maka akan ditemukan beberapa ciri; Pertama, ciri dari orang kafir, di dalam al-Qur'an orang kafir bersifat suka putus asa, tidak menikmati kedamaian dan ketentraman dalam kehidupannya, tidak mempercayai rukun iman yang selama ini menjadi pedoman dan keyakinan umat Islam, mereka tidak mau mendengarkan dan berfikir mengenai kebenaran yang diyakini oleh kaum Muslim, mereka lebih sering mengingkari janji, memiliki sikap sombong, dengki, dan cenderung memusuhi orang-orang beriman selain itu mereka juga suka kehidupan yang hedonis yaitu merupakan kehidupan yang berlandaskan pada hal-hal yang sifatnya material. Tujuan hidup mereka hanya kesuksesan duniawi saja, sehingga hal ini berdampak pada ketidakseimbangan kepribadian mereka dan menjadikan mereka tertutup akan pengetahuan ketauhidan.

Ciri dari orang kafir seperti yang digambarkan dalam al-Qur'an tersebut, menyebabkan mereka kehilangan keseimbangan dalam hal kepribadian mereka. Akibatnya, terjadi banyak penyimpangan kepribadian ke arah pemuasan syahwat, kesenangan lahiriah dan duniawi. Hal ini menjadikan mereka kehilangan tujuan dalam hidupnya yaitu beribadah kepada Allah Swt, serta mengharapkan ridha-Nya untuk mendapatkan ampunan (magrifah) dan memperoleh pahala dunia dan akhirat.

Kedua, kepribadian orang munafik, merupakan segolongan orang yang memiliki kepribadian sangat lemah dan bimbang. Diantara sifat atau watak orang munafik yang tergambar dalam al-Qur`an diantaranya; mereka "lupa" dan menuhankan sesuatu atau seseorang selain Allah Swt, dalam berbicara mereka selalu berdusta, mereka menutup pendengaran, penglihatan dan perasaannya dari kebenaran. Orang munafik merupakan kelompok manusia dengan kepribadian lemah, selalu ragu-ragu, dan tidak memiliki sikap yang tegas dalam masalah keimanan, mereka bersifat hiprokit, yakni sombong, angkuh dan cepat putus asa.

Ciri dari orang munafik yang paling mendasar yaitu kebimbangannya antara keimanan dan kekafiran serta ketidakmampuannya dalam membuat sikap yang tegas dan jelas berkaitan dengan keyakinan tauhid.

Berbicara mengenai kelemahan manusia, berarti membahas mengenai kelemahan manusia yang ada di dalam al-Qur'an, yang mana kelemahan tersebut lebih pada sifat, sikap atau prilaku manusia itu sendiri. Lalu, apa saja kelemahan manusia yang ada dalam al-Qur'an?

Namun sebelum itu terlebih dahulu harus diketahui bagaimana bentuk kelemahan manusia tersebut, apakah kelemahan itu memang ada atau sudah ada sejak awal diciptakannya manusia, atau kelemahan tersebut ada setelah proses dari penciptaan manusia, dimana kelemahan itu muncul karena sifat serta pengaruh keadaan yang menyebabkan manusia menjadi lemah.

Kelemahan manusia dibagi dua bagian, pertama; Kelemahan primer dan kedua; Kelemahan sekunder Pertama; Kelemahan primer yaitu kelemahan yang memang sudah ada sejak awal penciptaan manusia dan selalu melekat ataupun ada dalam diri manusia, diantaranya adalah: 1) Lemah Q.S an-Nisa` ayat 28. 2) Tergesa-gesa Q.S al-Isra` ayat 11, Q.S al-Anbiya`ayat 37 dan Q.S al-Ma`arij ayat 19-21. 3) Lalai dan lengah Q.S al-A raf ayat 172, Q.S al-A`raf ayat 179, Q.S al-A`raf ayat 205. 4) Pembantah Q.S al-Kahfi ayat 54 dan Q.S al-Nahl ayat 4. 5) Putus asa Q.S Hud ayat 9-10 dan Q.S Fushilat ayat 49. 6) Khianat Q.S an-Nisa` ayat 107.

Kedua; Kelemahan sekunder yaitu kelemahan yang ada setelah proses penciptaan manusia, dimana kelemahan itu ada karena sebab dan akibat yang menjadikan manusia itu lemah, diantaranya adalah: 1) Zalim Q.S al-Ahzab ayat 72 dan Q.S Ibrahim ayat 34. 2) Merugi Q.S al-Syams ayat 7-10 dan Q.S al-'Ashr ayat 1-3. 3) Kembali ke tempat yang rendah Q.S al-Tin ayat 4-5. 4) Mengikuti hawa nafsu Q.S Yusuf ayat 53 dan Q.S 
al-Qiyamah ayat 5. 5) Kikir Q.S ayat al-Isra` ayat 100 dan Q.S al-`Adiyat ayat 6-8. 6) Melampaui batas Q.S Yunus ayat 12 dan Q.S al-'Alaq ayat 6-7. 7) Lupa terhadap Allah Swt/ kafir Q.S al-Zumar ayat 8.

Dari kelemahan manusia yang ada, kelemahan tersebut juga terjadi karena adanya sebab dan akibat yang menjadikan manusia itu lemah. Adapun sebab dan akibat manusia lemah yaitu:

1. Sebab manusia lemah

a. Manusia diciptakan memang pada dasarnya lemah. (Q.S an-Nisa`ayat: 26-28).

b. $\quad$ Bergelimang dosa. (Q.S an-Nisa` ayat: 105-113, Q.S al-Syams ayat: 5-10).

c. Mendustakan ayat-ayat Allah Swt dan kemukjizatan al-Qur`an. (Q.S al-A`raf ayat: 172-178, Q.S al-A`raf ayat: 179-186, Q.S Yunus ayat: 1-20, Q.S Hud ayat: 8-16, Q.S al-Kahfi ayat: 5459, Q.S al-Anbiya`ayat: 37-47).

d. Lalai (Q.S al-A`raf ayat: 179-186).

e. Melakukan kedurhakaan dan kekufuran dan larut dalam kesenangan dunia yang sementara. (Q.S Yunus ayat: 1-20, Q.S Ibrahim ayat: 28-34, Q.S al-Qiyamah ayat: 1-15).

f. Suka membangkang dan berpaling menolak kebenaran. (Q.S Hud ayat: 8-16, Q.S al-'Alaq ayat: 6-19).

g. Suka mencemooh dan melecehkan tentang hari akhir. (Q.S Hud ayat: 8-16, Q.S al-Qiyamah ayat: 1-15).

h. Suka berputus asa terhadap nikmat Allah Swt dan kikir (Q.S Hud ayat: 8-16, Q.S al-Ma`arij ayat: 19-35, Q.S al-`Adiyat ayat: 6-11).

i. $\quad$ Bangga dan lupa diri saat mendapat nikmat. (Q.S Hud ayat: 8-16, Q.S. al-Isra`ayat: 82-100, Q.S al-Zumar ayat: 8, Q.S Fushilat ayat: 49-54).

j. $\quad$ Manusia larut dalam kesenangan dan kemewahan dunia. (Q.S Hud ayat: 8-16).

k. Mengikuti hawa nafsu. (Q.S Yusuf ayat: 50-53, Q.S al-Isra` ayat 9-15).

1. $\quad$ Khianat (Q.S Yusuf ayat: 50-53, Q.S al-Ahzab ayat: 70-73).

m. Durhaka dan mempersekutukan Allah Swt. (Q.S Ibrahim ayat: 28-34, Q.S al-Nahl ayat: 1-4, Q.S al-Zumar ayat: 8).

n. Tidak mengingat dari apa dia diciptakan. (Q.S al-Nahl ayat: 1-4).

o. $\quad$ Manusia tergesa-gesa. (Q.S. al-Isra`ayat: 9-15, Q.S al-Ma`arij ayat: 19-35)

2. Akibat manusia lemah.

a. Manusia mengikuti hawa nafsu dan melakukan kedurhakaan kepada Allah Swt dan berpaling dari kebenaran. (Q.S. an-Nisa` ayat 26-28, Q.S. al-A`raf ayat 172-178, Q.S. al-Isra` ayat: 9-15).

b. $\quad$ Sesat. (Q.S. al-A`raf ayat 172-178).

c. Zalim kepada diri sendiri. (Q.S al-A`raf ayat: 172-178, Q.S Ibrahim ayat: 28-34, Q.S al-Ahzab ayat: 70-73).

d. Seperti binatang ternak. (Q.S al-A`raf ayat: 179-186).

e. Masuk ke dalam neraka akibat kedurhakaan dan kekufuran mereka dan mendapat azab yang pedih (Q.S Yunus ayat: 1-20, Q.S al-Isra` ayat: 9-15, Q.S al-Isra` ayat 82-100, Q.S al-Kahfi ayat: 54-59, Q.S al-Anbiya ayat: 37-47, Q.S al-Ahzab ayat: 70-73, Q.S al-Zumar ayat: 8, Q.S Fushilat ayat: 49-54, Q.S al-Qiyamah ayat: 1-15, Q.S al-Tin ayat: 4-8, Q.S al-`Alaq ayat: 6-19, Q.S al-`Adiyat ayat: 6-11).

f. Lupa pada pertolongan yang Allah Swt berikan ketika mereka ditimpa kemudharatan. (Q.S Yunus ayat: 1-20, Q.S Fushilat ayat: 49-54).

g. Menyuruh kepada kejahatan dan keburukan. (Q.S Yusuf ayat: 50-53).

h. Tidak mendapat rahmat, petunjuk dan kecaman karena kekufuran pada al-Qur`an. (Q.S al-Isra` ayat: 82-100, Q.S Fushilat ayat: 49-54).

i. Ditutup hati, mata dan telinga dan tidak mendapat hidayah dari Allah Swt. (Q.S al-Kahfi ayat: 54-59).

j. $\quad$ Khianat. ( Q.S Yusuf ayat: 50-53, Q.S al-Ahzab ayat: 70-73).

k. Rugi (Q.S al-Syams ayat: 5-10).

1. Derajat direndahkan. (Q.S al-Tin ayat: 4-8)

Kemudian dari uraian kelemahan serta sebab dan akibat yang menjadikan manusia lemah, apa solusi al-Qur`an dalam mengatasi kelemahan manusia tersebut? Maka dari sekian banyaknya masalah yang menimpa manusia, hal itu tidak terjadi begitu saja dengan mudahnya. Akan tetapi Allah Swt. telah menakar terlebih dahulu kemampuan manusia dalam menghadapi masalah tersebut. Allah Swt. menimpakan masalah kepada manusia semata-mata agar manusia dapat mengambil hikmah dan pelajaran dari setiap permasalahan yang dihadapinya. Manusia yang sabar dalam menghadapi permasalahan yang ditimpakan kepadanya akan mendapatkan ganjaran pahala dari Allah Swt., sementara manusia yang tidak memiliki kesabaran akan timbul 
sifat arogan dan putus asa dalam dirinya sehingga tidak bernilai ibadah dan tidak mendapatkan pahala dari Allah Swt.

Sebagai contoh solusi yang diberikan Allah Swt dalam al-Qur'an yaitu surat al-Ma`arij ayat 19-21, Allah Swt memberikan jawaban pada ayat: 22-35

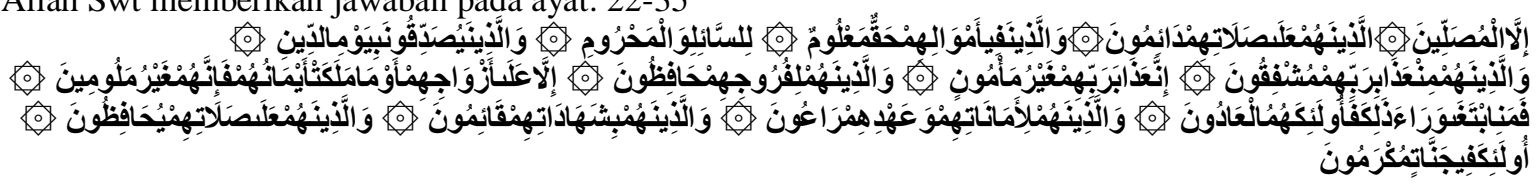

Artinya: "Kecuali orang-orang yang mengerjakan shalat, yang mereka itu tetap mengerjakan shalatnya, dan orang-orang yang dalam hartanya tersedia bagian tertentu, bagi orang (miskin) yang meminta dan orang yang tidak mempunyai apa-apa (yang tidak mau meminta), dan orang-orang yang mempercayai hari pembalasan, dan orang-orang yang takut terhadap azab Tuhannya. Karena sesungguhnya azab Tuhan mereka tidak dapat orang merasa aman (dari kedatangannya). Dan orang-orang yang memelihara kemaluannya, kecuali terhadap isteri-isteri mereka atau budak-budak yang mereka miliki, maka sesungguhnya mereka dalam hal ini tiada tercela. Barangsiapa mencari yang di balik itu, maka mereka itulah orang-orang yang melampaui batas. Dan orang-orang yang memelihara amanat-amanat (yang dipikulnya) dan janjinya. Dan orang-orang yang memberikan kesaksiannya. Dan orang-orang yang memelihara shalatnya. Mereka itu (kekal) di surga lagi dimuliakan.” (Q.S al-Ma`arij ayat: 22-35)

Ayat ini dapat dihubungkan dengan ayat sebelumnya, seakan-akan Allah Swt menyatakan bahwa ada orang-orang yang tidak menyandang sifat-sifat yang disebut sebelumnya; mereka itu adalah para yang shalat dan melaksanakannya secara tetap dan pada waktunya. Pengecualian ini mengesankan bahwa sifat-sifat yang disebutkan sebelumnya merupakan sifat-sifat yang buruk yang tidak disandang oleh orang-orang mukmin. Banyak ulama tafsir masa lalu yang memahaminya demikian. Tetapi, ulama kontemporer, antara lain Thabathabai dan Ibn `Asyur, menegaskan bahwa sifat yang diuraikan ayat-ayat yang lalu adalah sifat bawaan manusia, hanya saja kedua ulama ini berbeda pendapat tentang pengecualian tersebut. Thabathabai memahaminya berhubungan dengan ayat-ayat sebelumnya secara langsung, hanya saja ulama ini menegaskan bahwa pengecualian orang-orang yang melaksanakan shalat dan lain-lain bukan berarti bahwa mereka tidak dilengkapi dengan naluri itu, tetapi bahwa mereka menggunakannya sesuai dengan tuntunan Allah Swt serta memfungsikannya sesuai dengan fungsinya yang sebenarnya. Ayat diatas bagaikan menyatakan: Kecuali para yang shalat yang mereka itu menyangkut shalat mereka tetap melakukannya pada waktunya secara bersinambung tanpa meninggalkan satu shalat pun. (M. Quraish Shihab : 2012)

Thahir Ibn 'Asyur tidak memahami pengecualian itu berkaitan dengan bawaan manusia yang disebutkan oleh ayat 19 dan yang dijelaskan maknanya oleh ayat $20-21$. Tetapi, menurutnya, ayat 22 itu berkaitan dengan firman Allah Swt pada ayat 11 yang lalu. Ayat 22 itu menurutnya, bagaikan berkata: Para pendurhaka berkeinginan untuk menebus dirinya dengan anak-anak mereka agar terhindar dari siksa, tetapi para yang shalat yang mereka itu menyangkut shalat mereka tetap melakukannya pada waktunya secara bersinambung serta menyandang pula sifat-sifat seperti yang disebut berikut. Mereka itu tidak akan mengalami siksa dan akan masuk ke surga.

Setelah manusia mengerjakan shalat jelaslah bahwa imannya kepada Allah Swt telah bertambah kokoh dan meluas. Dia ingat akan kewajibannya kepada sesama hamba Allah Swt, sebab islam itu sendiri mendidik demikian, terutama shalat itu sendiri, bukanlah semata-mata mengokohkan iman kepada Allah Swt, bahkan juga iman akan apa yang diperintahkan Allah Swt. Diantara yang diperintahkan Allah Swt sesudah perintah shalat ialah menyediakan sebahagian daripada harta untuk membantu orang-orang yang patut dibantu; bernama zakat. Baik zakat kekayaan, ataupun zakat pertanian, atau zakat peternakan.

Begitu juga dengan orang-orang yang membenarkan hari pembalasan, yaitu orang-orang yang percaya sungguh dia bahwasanya di belakang hidup kita yang sekarang ini, ada lagi hidup sesudah mati, untuk menerima ganjaran dari pada amal yang dikerjakan pada masa hidup yang pertama ini, baik mendapat balasan baik, buruk mendapat pembalasan buruk. Dan orang-orang yang takut terhadap azab Tuhannya. Karena sesungguhnya azab Tuhan mereka tidak dapat orang merasa aman (dari kedatangannya). Dan orang-orang yang memelihara kemaluannya, artinya alat kelamin laki-laki dan perempuan. Dalam ayat ini disebut bahwa salah satu ciri orang yang beriman ialah yang menjaga dan memeliharanya, Kecuali terhadap isteri-isteri mereka atau budak-budak yang mereka miliki, maka sesungguhnya mereka dalam hal ini tiada tercela.

Dan orang-orang yang memelihara amanat-amanat (yang dipikulnya) dan janjinya, inilah sambungan dari sifat-sifat utama orang yang shalat, dan tetap dalam shalatnya. Mereka tetap shalat dan sebagai akibat dari shalat yang tetap itu ialah mereka memegang teguh amanat-amanat. Mereka pelihara, mereka jaga, 
jangan sampai amanat dihkhianati, jangan sampai janji dimungkiri. Karena kalau amanat dan janji telah tidak dipelihara lagi, alamat penyakit munafik telah menyerang diri, yang sukar mengobatnya.

Dan orang-orang yang memberikan kesaksiannya, terjadi kesulitan di antara manusia sesama manusia. Kadang-kadang timbul masalah yang terpaksa dibawa ke muka pengadilan. Hakim memerlukan seorang saksi, maka seorang yang diminta kesaksiannya karena dia mengetahui duduk perkara, hendaklah memberikan keterangan dengan jujur, sehingga jalan pemeriksaan perkara tidak sulit dan keputusan mudah diambil oleh hakim. Kesaksian palsu, atau kesaksian yang mengandung dusta atau menyembunyikan hal yang sebenarnya, disebut dengan "Syahadatuz-Zur", artinya kesaksian dusta. Kesaksian dusta termasuk salah satu di antara tujuh dosa besar.

Dan orang-orang yang memelihara shalatnya, pada ayat sebelumnya ayat 23, Allah Swt telah menyebutkan sifat utama orang yang beriman, yaitu shalat. Pada ayat ini diulang sekali lagi, yaitu bahwa sembahyangnya itu terpelihara baik-baik.

Ada orang yang selalu melaksanakan shalat, asal waktu telah masuk dia segera menunaikan shalat, tetapi belum tentu shalatnya itu dipeliharanya. Shalat yang terpelihara ialah yang dikerjakan dengan khusyu` dan tertib, dengan thuma`ninah (tenang), lengkap rukun dan syaratnya, kokoh ruku` dan sujudnya, bukan seperti burung layang-layang yang jelas benar bahwa dia ingin selesai lekas, seakan-akan mengahadapi Tuhan itu dianggapnya mengikat dirinya dan menghalangi pekerjaan yang lain.

Pada ayat 35, Allah Swt menyebutkan, bahwa Mereka itu (kekal) di surga lagi dimuliakan, diujung ayat ini Allah Swt menjanjikan bahwa orang-orang itu akan dimuliakan di dalam syurga-syurga yang telah disediakan. ( Hamka : 1988)

Kemudian firman Allah Swt dalam surat al-Qiyamah ayat 5, dimana Allah Swt menceritakan tentang orang-orang yang durhaka dan menolak kebenaran Ilahi menjadi muram durja.

Kadang-kadang lupalah manusia akan perhitungan Hari Depan itu, bahwasanya ada lagi sambungan hidup, karena lupa itu diperturutkannyalah al-Nafsul Amarah, yaitu nafsu yang mendorong akan berbuat salah, dalam ilmu modern disebut instinct kebinatangan yang ada dalam diri manusia. Dia berbuat sesuka hati, asal yang akan memuaskan kehendaknya saja, setelah dia terlanjur berbuat salah, atau setelah gejala alNafsul Amarah itu mereda atau turun, atau lindap ibarat api, timbullah sesal, mengapa menyesal? Sebab awak manusia. Seekor binatang yang berkelahi sesamanya binatang, sampai badannya luka-luka, tidaklah akan ada rasa penyesalan karena merasa bersalah, tetapi manusia mempunya rasa penyesalan itu.

Said bin Jubair, murid Ibn Abbas dalam hal tafsir mengatakan: "Lawwamah" ialah penyesalan atas diri sendiri karena berbuat salah, menyesali diri sendiri karena kebajikan yang diperbuat rasanya masih kurang. Mujahid mengatakan: "Menyesali keterlanjuran masa lampau".

Al-Hasan al-Bishri menjelaskannya lagi; "Orang yang beriman itu senantiasa menyesali serba kekurangan yang ada pada dirinya. Mengapa aku bertutur demikian, mengapa aku makan minum secara demikian, apa yang aku maukan atas diriku ini. Sedang orang yang durhaka kepada Tuhan maju terus berbuat dosa, kemudian sekali barulah dia menyesal.

Sikap angkuh dan dan masa bodoh yang ada pada diri manusia sebenarnya dipicu oleh kecintaannya yang sangat dalam terhadap harta dan dunia ini, sehingga ia merasa akan hidup selama-lamanya di dunia ini. Manusia bermegah-megahan dalam hal dunia, sehingga kecintaannya pada materi dan kebendaan menjadi sangat mengkristal dan sulit dikikis, inilah yang Nabi Muhammad Saw sebut dengan istilah "al-wahn", yaitu mencintai dunia dan takut dengan kematian. Dan saat kematian itu datang ia terperangah dan terkejut, karena ia benar-benar tidak memperkirakan sebelumnya, bahkan ia berfikir akan hidup selama-lamanya.

Saat orang-orang yang ingkar dan tidak takut dengan kematian karena kecintaanya pada dunia, saat sakaratul dihadapinya ia benar-benar tidak memilki daya apapun, yang ia tahu bahwa saat perpisahan dengan segala yang dicintainya akan segera terjadi, semua sangkaannya akan menjadi sia-sia. Hari yang ia takuti akan segara datang, saat yang paling ia benci akan menyambanginya. Segala keangkuhan dan kekuasaannya, juga hartanya tidak akan mampu menggantikan suasana ketakutan yang ia hadapi.

Adapun bagi orang-orang yang beriman, hari pertemuan dengan Tuhan-nya adalah hari penantian yang sangat membahagiakan, hari yang sempurna bagi orang-orang yang beriman, karena mereka bisa melihat dan bertemu langsung dengan Allah Swt tanpa ada hijab dan penghalang sedikitpun. Karena itu orang beriman tidak pernah takut mati, justru ia sangat mencintai kematian.

Bila kita lihat berbagai penafsiran dari para ulama tafsir, maka kita bisa menyimpulkan bahwa manusia melakukan dosa besar, diantaranya adalah; a) Mendustakan Allah Swt dan Rasul-Nya; yaitu tidak menerima segala hal yang dibawa olehnya, termasuk al-Qur`an, b) Tidak mau mengerjakan shalat; ini adalah sebuah simbol keangkuhan, bentuk kesombongan yang sangat dimurkai oleh Allah Swt, karena kebesaran hanya milik-Nya, c) Berpaling dari kebenaran karena ego dan gengsinya; sebagai akibat ia tidak mau lagi mendengarkan nasihat dan masukan konstruktif, ia abaikan kebenaran, ia palingkan dirinya menjauhi 
kebenaran demi gengsi dan egonya, apalagi kebenaran itu datang dari orang yang tidak disukainya atau karena ancaman popularitasnya atau takut kehilangan pengaruh di tengah kaumnya, d) Sombong di depan manusia; pada ayat 33 secara spesifik Allah Swt menggambarkan ia berlaku sombong di depan keluarganya. Jika ia sudah berani berlaku sombong dan angkuh di depan keluarganya apalagi di depan orang lain, ia berinteraksi dengan kasar dan keras demi menujukkan keangkuhannya. Maka jatuhlah vonis celaka terhadap mereka dan apa yang mereka lakukan. (Ibn Jarir al-Thabary: 2001)

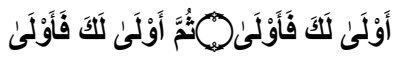

Artinya: "Kecelakaanlah bagimu (hai orang kafir) dan kecelakaanlah bagimu, kemudian kecelakaanlah bagimu (hai orang kafir) dan kecelakaanlah bagimu”. (Q.S al-Qiyamah ayat: 34-35)

Kecaman dan kutukan pada ayat di atas diulang sampai empat kali, pertama; saat ia meregang nyawa menghadapi kematian, kedua; saat ia berada dalam kesendirian tanpa daya mendapatkan siksa kubur, ketiga; saat ia dibangkitkan setelah hari kehancnuran, dan keempat; saat vonis terakhir benar-benar ia terima, mendekam dalam kekekalan di neraka Jahannam sepanjang masa, dan hanya Allah Swt yang tahu takarannya, dan ia tidak pernah merasakan bahwa wujud serta eksistensinya di dunia ini adalah sebuah kenikmatan yang Maha Agung. "Bukankah dia dahulu setetes mani yang ditumpahkan (ke dalam rahim), kemudian mani itu menjadi segumpal darah, lalu Allah Swt menciptakannya, dan menyempurnakannya, lalu Allah Swt menjadikan daripadanya sepasang: laki-laki dan perempuan”. (Q.S al-Qiyamah ayat: 37-39).

Jika manusia mengingat asal kejadiannya, ia akan segera sadar dan tahu bahwa Allah Swt mampu membangkitkannya setelah mematikan seluruh makhluk-Nya, "Bukankah (Allah Swt yang berbuat) demikian berkuasa (pula) menghidupkan orang mati?”. (Q.S al-Qiyamah ayat: 40).

Jika manusia tidak lalai dan mau mengingat asal usulnya, tentu ia akan jauh dari petaka dan azab Allah Swt ketika berada di dunia, sebagai gantinya kelak di akhirat akan Allah Swt berikan kesempatan yang sangat mulia, yaitu bertemu langsung dengan-Nya dan itu adalah kenikmatan yang sangat besar bagi orangorang yang beriman di akhirat kelak.

Tabel 1. Ayat-ayat yang Berbicara tentang Kelemahan Manusia serta Solusi Al-Qur`an dalam Mengatasi Kelemahan Manusia:

\begin{tabular}{|c|c|}
\hline Surat & Solusi al-Qur`an \\
\hline Surat an-Nisa`ayat: $26-28$ & $\begin{array}{l}\text { a. Karena lemahnya manusia, Allah Swt memberikan keringanan } \\
\text { kepada manusia atas hukum-hukum yang diberikan. }\end{array}$ \\
\hline \multirow[t]{2}{*}{ Surat an-Nisa`ayat: 105-113 } & $\begin{array}{l}\text { a. Ingat dan mohon ampun kepada Allah Swt dari segala bentuk } \\
\text { khianat dan dosa. }\end{array}$ \\
\hline & $\begin{array}{l}\text { b. Berpegang teguh kepada Kitab yang Allah Swt turunkan sebagai } \\
\text { pedoman dalam kehidupan. }\end{array}$ \\
\hline \multirow[t]{2}{*}{ Surat al-A'raf ayat: $172-178$} & $\begin{array}{l}\text { a. Mengelola pola fikir yang ada di dalam diri dengan bimbingan al- } \\
\text { Qur`an yang telah Allah Swt turunkan. }\end{array}$ \\
\hline & b. Mencari hidayah dan petunjuk yang ada di dalam al-Qur`an. \\
\hline \multirow[t]{5}{*}{ Surat al-A`raf ayat: $179-186$} & $\begin{array}{l}\text { a. Mengambil pelajaran terhadap apa yang terbentang di langit dan } \\
\text { di bumi. }\end{array}$ \\
\hline & $\begin{array}{l}\text { b. Mengingat bahwa seolah-olah ajal telah dekat } \\
\text { (kebinasaan/kematian). }\end{array}$ \\
\hline & $\begin{array}{l}\text { c. Menggunakan hati, mata dan telinga untuk melihat dan } \\
\text { memahami ayat dan kekuasaan Allah Swt. }\end{array}$ \\
\hline & d. Meminta dan memohon petunjuk hanya kepada Allah Swt. \\
\hline & $\begin{array}{l}\text { e. Mengikuti risalah dan petunjuk yang dibawa oleh Nabi } \\
\text { Muhammad Saw. }\end{array}$ \\
\hline \multirow[t]{3}{*}{ Surat Yunus ayat: $1-20$} & $\begin{array}{l}\text { a. Beriman dan beramal saleh, dan mendapat petunjuk dari Allah } \\
\text { Swt karena keimanan. }\end{array}$ \\
\hline & $\begin{array}{l}\text { b. Mentadabburi dan memikirkan pada penciptaan langit dan bumi, } \\
\text { serta pada pergantian siang dan malam. }\end{array}$ \\
\hline & c. Menjadikan al-Qur`an sebagai pedoman dalam kehidupan. \\
\hline \multirow[t]{2}{*}{ Surat Hud ayat: $8-16$} & $\begin{array}{l}\text { a. Selalu bersabar dan bersyukur pada setiap nikmat dan cobaan } \\
\text { yang Allah Swt berikan. }\end{array}$ \\
\hline & b. Menjadikan al-Qur`an pedoman kehidupan. \\
\hline
\end{tabular}




\begin{tabular}{|c|c|}
\hline Surat & Solusi al-Qur`an \\
\hline Surat Yusuf ayat: 50-53 & $\begin{array}{l}\text { a. Meminta rahmat dan perlindungan dari Allah Swt agar terhindar } \\
\text { dari nafsu yang buruk. }\end{array}$ \\
\hline \multirow[t]{2}{*}{ Surat Ibrahim ayat: $28-34$} & $\begin{array}{l}\text { a. Melihat dan memperhatikan akan keesaan dan kekuasaan Allah } \\
\text { Swt yang ada di langit dan bumi. }\end{array}$ \\
\hline & $\begin{array}{l}\text { b. Selalu melaksanakan shalat dan menginfaq-kan setiap rezeki } \\
\text { yang Allah Swt berikan. }\end{array}$ \\
\hline \multirow[t]{2}{*}{ Surat al-Nahl ayat: $1-4$} & $\begin{array}{l}\text { a. Melihat dan merenungkan ciptaan Allah Swt, yaitu langit dan } \\
\text { bumi yang menunjukkan keesaan dan kekuasaan Allah Swt. }\end{array}$ \\
\hline & $\begin{array}{l}\text { b. Kematian pasti akan datang maka hendaklah selalu } \\
\text { mempersiapkan apa yang akan dibawa untuk kematian. }\end{array}$ \\
\hline \multirow[t]{3}{*}{ Surat al-Isra` ayat: $9-15$} & a. Pahala yang besar bagi orang yang beriman. \\
\hline & b. Menjadikan al-Qur`an sebagai pedoman dalam kehidupan. \\
\hline & c. $\quad$ Berusaha dan mencari hidayah Allah Swt. \\
\hline \multirow[t]{2}{*}{ Surat al-Isra` ayat: $82-100$} & $\begin{array}{l}\text { a. Orang beriman menjadikan al-Qur`an pedoman dan penawar hati } \\
\text { dalam kehidupan. }\end{array}$ \\
\hline & b. Hidayah bagi orang yang mengimani al-Qur`an. \\
\hline Surat al-Kahfi ayat: 54-59 & $\begin{array}{l}\text { a. Ampunan dan ditangguhkan turunnya azab kepada manusia } \\
\text { supaya bertaubat dan diberikannya peluang bagi manusia agar } \\
\text { mereka sadar dan bertaubat sebelum ditimpakan azab kepada } \\
\text { mereka. }\end{array}$ \\
\hline \multirow[t]{2}{*}{ Surat al-Anbiya`ayat: $37-47$} & $\begin{array}{l}\text { a. Rahmat yang Allah Swt curahkan kepada manusia di siang dan } \\
\text { malam agar manusia bersyukur. }\end{array}$ \\
\hline & $\begin{array}{l}\text { b. Peringatan (al-Qur`an) yang Allah Swt turunkan kepada Rasul- } \\
\text { Nya sebagai pedoman hidup. }\end{array}$ \\
\hline \multirow[t]{2}{*}{ Surat al-Ahzab ayat: $70-73$} & $\begin{array}{l}\text { a. Allah Swt menerima taubat bagi orang-orang yang menjalankan } \\
\text { amanat dengan baik. }\end{array}$ \\
\hline & b. Balasan untuk orang-orang yang beriman. \\
\hline \multirow[t]{3}{*}{ Surat al-Zumar ayat: 8} & $\begin{array}{l}\text { a. Beribadah di waktu siang dan malam, dan berharap rahmat Allah } \\
\text { Swt. }\end{array}$ \\
\hline & b. $\quad$ Bersabar dan selalu berdoa kepada Allah Swt. \\
\hline & $\begin{array}{l}\text { c. Kebahagian untuk orang-orang yang beriman dan bertakwa di } \\
\text { dunia begitu juga di akhirat. }\end{array}$ \\
\hline Surat Fushilat ayat: $49-54$ & $\begin{array}{l}\text { a. Memahami bukti kekuasaan Allah Swt yang terdapat dalam al- } \\
\text { Qur`an. }\end{array}$ \\
\hline Surat al-Ma`arij ayat: 19-35 & $\begin{array}{l}\text { a. Menjaga shalat, bersedekah (berinfaq) dijalan Allah Swt, takut } \\
\text { terhadap siksa Allah Swt diakhirat kelak, menjaga kemaluan } \\
\text { mereka, menjaga amanat dan memberi kesaksian dalam } \\
\text { kebenaran. }\end{array}$ \\
\hline \multirow[t]{2}{*}{ Surat al-Qiyamah ayat: $1-35$} & a. Membenarkan Rasul dan al-Qur`an. \\
\hline & $\begin{array}{l}\text { b. Wajah berseri-seri orang yang beriman ketika bertemu dengan } \\
\text { Allah Swt karena amalan shaleh mereka ketika di dunia. }\end{array}$ \\
\hline Surat al-Syams ayat: 5-10 & $\begin{array}{l}\text { a. Keberuntungan bagi orang yang menyucikan jiwa dengan } \\
\text { mengikuti tuntunan Allah Swt dan Rasul-Nya. }\end{array}$ \\
\hline Surat al-Tin ayat: $4-8$ & $\begin{array}{l}\text { a. Ganjaran pahala yang tidak pernah putus bagi orang yang } \\
\text { beriman dan beramal saleh. }\end{array}$ \\
\hline Surat al-`Alaq ayat: 6-19 & $\begin{array}{ll}\text { a. Anjuran untuk selalu sujud dan mendekatkan diri kepada Allah } \\
\text { Swt. }\end{array}$ \\
\hline Surat al-'Adiyat ayat: 6-11 & - \\
\hline Surat al-`Ashr ayat: 1-3 & $\begin{array}{l}\text { a. Orang beriman, beramal saleh, berwasiat dalam kebenaran dan } \\
\text { kesabaran akan beruntung di akhirat nanti. }\end{array}$ \\
\hline
\end{tabular}




\section{SIMPULAN}

Kelemahan manusia dalam al-Qur`an dibagi menjadi dua bagian yaitu; Kelemahan primer dan sekunder. Kelemahan primer adalah: Kelemahan yang memang sudah ada sejak awal penciptaan manusia dan selalu melekat ataupun ada dalam diri manusia. Sedangkan kelemahan sekunder adalah: Kelemahan yang ada setelah proses penciptaan manusia, dimana kelemahan itu ada karena sebab dan akibat yang menjadikan manusia itu lemah. Dalam al-Qur`an kelemahan primer terbagi pada: 1) Lemah, 2) Tergesa-gesa, 3) Lalai dan lengah, 4) Pembantah, 5) Putus asa, dan 6) Khianat. Kelemahan sekunder terbagi pada: 1) Zalim, 2) Merugi, 3) Kembali ke tempat yang rendah, 4) Mengikuti hawa nafsu, 5) Kikir, 6) Melampaui batas, 7) Lupa terhadap Allah Swt/ kafir.

Kelemahan manusia yang ada dalam al-Qur`an, ada faktor sebab dan akibat yang menjadikan manusia lemah. Sebab manusia lemah adalah: 1) Manusia diciptakan memang pada dasarnya lemah, 2) Bergelimang dosa, 3) Mendustakan ayat-ayat Allah Swt dan kemukjizatan al-Qur`an, 4) Lalai, 5) Melakukan kedurhakaan dan kekufuran dan larut dalam kesenangan dunia yang sementara, 6) Suka membangkang dan berpaling menolak kebenaran, 7) Suka mencemooh dan melecehkan tentang hari akhir, 8) Suka berputus asa terhadap nikmat Allah Swt dan kikir, 9) Bangga dan lupa diri saat mendapat nikmat, 10) Manusia larut dalam kesenangan dan kemewahan dunia, 11) Mengikuti hawa nafsu, 12) Khianat, 13) Durhaka dan mempersekutukan Allah Swt, 14) Tidak mengingat dari apa dia diciptakan, 15) Manusia tergesa-gesa. Akibat manusia lemah adalah: 1) Manusia mengikuti hawa nafsu dan melakukan kedurhakaan kepada Allah Swt dan berpaling dari kebenaran, 2) Sesat, 3) Zalim kepada diri sendiri, 4) Seperti binatang ternak, 5) Masuk ke dalam neraka akibat kedurhakaan dan kekufuran mereka dan mendapat azab yang pedih, 6) Lupa pada pertolongan yang Allah Swt berikan ketika mereka ditimpa kemudharatan, 7) Menyuruh kepada kejahatan dan keburukan, 8) Tidak mendapat rahmat, petunjuk dan kecaman karena kekufuran pada al-Qur`an, 9) Ditutup hati, mata dan telinga dan tidak mendapat hidayah dari Allah Swt, 10) Khianat, 11) Rugi, 12) Derajat direndahkan.

Dari berbagai macam bentuk kelemahan manusia yang ada dalam al-Qur`an, baik itu kelemahan primer ataupun sekunder, dimana kelemahan itu terjadi karena sebab dan akibat yang menjadikan manusia itu lemah, al-Qur`an memberikan solusi terhadap kelemahan manusia tersebut, diantara solusi yang diberikan alQur`an adalah: 1) Memohon ampun dan perlindungan kepada Allah Swt dari segala bentuk perbuatan tercela, 2) Menggunakan mata, hati dan telinga untuk melihat dan memahami ayat dan kekuasaan Allah Swt, 3) Allah Swt berikan keringan atas hukum-hukum yang diberikan kepada manusia, 4) Menjadikan al-Qur`an pedoman kehidupan, 5) Beriman dan beramal saleh, dan mendapat petunjuk dari Allah Swt karena keimanan, 6) Kematian pasti akan datang maka hendaklah selalu mempersiapkan apa yang akan dibawa untuk kematian, 7) Ampunan dan ditangguhkan turunnya azab kepada manusia supaya bertaubat dan diberikannya peluang bagi manusia agar mereka sadar dan bertaubat sebelum ditimpakan azab kepada mereka, 8) Rahmat yang Allah Swt curahkan kepada manusia di siang dan malam agar manusia bersyukur, 9) Menjaga shalat, bersedekah (berinfaq) dijalan Allah Swt, takut terhadap siksa Allah Swt diakhirat kelak, menjaga kemaluan mereka, menjaga amanat dan memberi kesaksian dalam kebenaran, 10) Membenarkan Rasul dan al-Qur`an, 11) Keberuntungan bagi orang yang menyucikan jiwa dengan mengikuti tuntunan Allah Swt dan Rasul-Nya, 12) Ganjaran pahala yang tidak pernah putus bagi orang yang beriman dan beramal saleh, 13) Orang beriman, beramal saleh, berwasiat dalam kebenaran dan kesabaran akan beruntung di akhirat nanti.

\section{REFERENSI}

Brubacher, J. S. (1950). Modern phlisopies of education. New York: Mc Graw Hill Book Comapny INC. Al-Faruqi, I. R. (184). Islam dan kebudayaan. Bandung: Mizan.

Ihsan, H. (2007). Filsafat pendidikan Islam. Bandung: Pustaka Setia.

Zakaria, A. a.-H.(t.th). Mujam Maqayis al-Lughah. Beirut: Ittihad al-Kitab al-A'rab.

Al-Baqi, M. F. A. (1998). Al-Mu`jam al-Mufahras li al-Faazh al-Qur'an al-Karim. Kairo: Daar el-Hadits.

Al-Haim, S. a-D. (1992). Al-Tibyan fi Tafsir Garib al-Qur`an. Qahirah: Daar el-Shahabah.

Al-Ashfahani, R. (t.th). Al-Mufradat fi Garib al-Qur`an. Beirut: Daar el-Ma`arif.

Asy`ari, M. (1992). Manusia pembentuk kebudayaan dalam al-Qur`an. Yogyakarta: LESFI.

Fay, B. (2002). Filsafat ilmu sosial kontemporer. Yogyakarta: Jendela.

Terjemahan al-Qur'an off-line "Ayat-v1.1.0_hudhaify.

Shihab, M. Q, (1994). Membumikan al-Qur`an. Mizan.

Muthahhari, M. \& Baqir, H. (1997). Perspektif al-Qur`an tentang manusia dan agama. Bandung: Penerbit Mizan.

http://kirjasto.sci.fi/ecanetti.htm diakses pada tanggal 31 januari 2020 
Najati, M. U. (Usmani, A. R). (t.th). Al-Qur`an wa ilmu al-nafs (Al-Qur`an dan ilmu jiwa). Shihab, M. Q. (2012). Tafsir al-mishbah. Jakarta: Lentera Hati.

Hamka, (1988). Tafsir al-azhar. Jakarta: Pustaka Panjimas.

Al-Thabary, I. J. (2001). Jami`al-bayan. Beirut: Dar Ihya` Turats.

Katsir, I. (t.th). Tafsir al-Qur'an al-'azhim. Kairo: Marktabah al-Qayyimah 